\title{
Plano Municipal de Educação \\ e a afirmação de princípios \\ para a educação local
}

- Flávia Obino Corrêa Werle ${ }^{1}$

Jorge Alberto Soares Barcellos ${ }^{2}$

\section{Resumo}

O texto discute um elemento de política pública, o Plano Municipal de Educação (PME) da cidade de Porto Alegre, Rio Grande do Sul, Brasil. Analisa o Plano em suas diferentes partes e a tramitação no Legislativo e no Conselho Municipal de Educação de Porto Alegre. Considera os atores envolvidos nos diferentes momentos do processo, os discursos afirmados e os negados, ideologias e visões de mundo. $O$ conteúdo do texto é importante, pois sugere elementos para avaliar o PME como um documento de política educacional numa perspectiva reflexiva. Indica como são sustentados/ articulados os discursos no PME, a forma ambígua com que os atores registram sua presença/escrita e responsabilizam-se pelo PME em suas diferentes fases. O Plano Nacional de Educação como um paradigma dilui e abafa uma possível abordagem cognitivo-interpretativa mais peculiar do mundo que o PME possa representar no âmbito do município.

Palavras-chave: Política educacional. Planejamento. Educação municipal.

\section{The Municipal Education Plan and the affirmation of principles for a local education Abstract}

The text discusses an element of public politics, the Municipal Education Plan (PME) of the city of Porto Alegre, Rio Grande do Sul, Brazil. It analyzes the Plan in its different stages and in its Legislative and Municipal Education Council process. It considers the actors involved in the different moments of the process, the affirmed and denied speeches, ideologies and world's point of views. The text's content is important because it suggests elements to evaluate the PME as an educational policy paper in a reflexive perspective. It indicates how the speeches in PME are maintained/articulated, the ambiguous way which the actors record their presence/writing and make themselves responsible for the PME in its different phases, the National Plan of Education as a paradigm that dilutes and stifles a possible cognitive-interpretative peculiar approach of the world that the PME may represent in the scope of the town.

Keywords: Educational politics. Planning. Municipal education.

\footnotetext{
1 Pós-Doutorado em Educação, Universidade do Minho, Portugal; Professora do Programa de Pós- Graduação em Educação da Universidade do Vale do Rio dos Sinos (UNISINOS), RS. E-mail: flavia@hello.unisinos.br

${ }^{2}$ Doutor em Educação, UNISINOS, RS; Coordenador do Memorial da Câmara Municipal de Porto Alegre, RS.
} 


\section{Plan Municipal de Educación y la afirmación de principios para la educación local \\ Resumen}

El texto discute un elemento de política pública, el Plan Municipal de Educación (PME) de la ciudad de Porto Alegre, Rio Grande do Sul, Brasil. Analiza el Plan en sus diferentes partes y la tramitación en el Legislativo y en el Consejo Municipal de Educación/POA. Considera los actores participantes en los diferentes momentos del proceso, los discursos afirmados y los negados, ideologías e visones de mundo. El contenido del texto es importante pues, sugiere elementos para evaluar el PME como un documento de política educacional en una perspectiva reflexiva. Indica como son sustentados/articulados los discursos en el $P M E$, a forma ambigua con que los actores registran su presencia/escrita y se responsabilizan por el PME en sus diferentes fases, el Plan Nacional de Educación como un paradigma que diluye e sofoca un posible abordaje cognitivo-interpretativo más peculiar del mundo que lo PME pueda representar en el ámbito del municipio.

Palabras clave: Política educacional. Planeamiento. Educación municipal.

\section{Introdução}

Este texto trata do processo legislativo que constituiu o Plano Municipal de Educação (PME) de Porto Alegre, revelando a participação do movimento social articulado que, por meio de um fórum, o produziu. Em seus diversos documentos ou partes, o processo é revelador de ideologias e visões de mundo; indica discursos que foram afirmados e os que lutam para se expressar; é fonte privilegiada para a compreensão do modo como são construídas, na prática, as políticas educacionais. Evidencia-se na análise aqui produzida a consideração de aspectos importantes das políticas públicas educacionais referentes a documentos escritos e atores do campo das políticas educacionais, quais sejam, colegiados, fórum com representação de diferentes entidades, legislativo e executivo municipal, pareceres, projetos de lei e planos. $\bigcirc$ estudo a que este artigo se propõe descreve e analisa cada parte dos documentos que foram produzidos pelos diferentes atores. $\bigcirc$ objetivo da análise é a verificação do grau de consistência interna do documento, considerando se os pressupostos declarados evidenciam-se em seu texto.

foco da análise são, predominantemente, os conteúdos concretos do PME, na dimensão material de policy e o processo político, politics, tomando o PME como uma política estruturadora (FREY, 2000), capaz de definir focos, instituições, processos referentes ao campo da educação municipal para os próximos dez anos. TrabaIharemos também com a base teórica de Cortesão, Magalhães e Stoer (2001), especificamente na ênfase que atribuem aos tradutores das políticas e à importância das opções tanto dos políticos que concebem as amplas mudanças políticas e, de alguma forma, as políticas concretas (comunidade acadêmica, partidos políticos, sindicatos, associações profissionais), como dos implementadores das políticas (burocratas, professores, pais) embora esses autores atribuam conteúdos diversos aos apresentados por Frey (2000), para as expressões politics e policies. 
A análise empreendida nesse artigo considera predominantemente dois contextos (LOPES, 2004; BALL, 2001): o da ampla esfera em que os discursos e argumentos são construídos nos quais as interpretações e recontextualizações de propostas políticas são constantes, bem como o da produção de textos legais, no caso, o texto do PME de Porto Alegre ${ }^{3}$, o Parecer do Conselho Estadual de Educação, o Projeto de Lei e a justificativa do Executivo.

\section{Situando a questão}

Em 14 de dezembro de 2004, João Verle ${ }^{4}$, então chefe do Executivo de Porto Alegre, encaminha à Câmara Municipal de Porto Alegre, para apreciação, o Projeto de Lei do Executivo - PLE - nº. 62/2004 (PORTO ALEGRE, 2004c). Composto por apenas 6 artigos, o projeto inclui também uma série de documentos que justificam a importância do PME e a íntegra do documento tal como foi aprovado pelo III Congresso Municipal de Educação, realizado de 26 a 30 de novembro de 2004. O processo finalizava um extenso trabalho de um ano de duração envolvendo mais de 40 entidades e realizando no município os objetivos de diversos instrumentos legais, quais sejam, planejar, a longo prazo, os rumos da educação no município de Porto Alegre.

projeto em análise é composto por três partes principais. A primeira é uma justificativa, na qual o Prefeito João Verle apresenta os aspectos legais e objetivos para aprovação da lei pelo legislativo; a segunda é o parecer do Conselho Municipal de Educação (CME), aprovando as diretrizes e metas elaboradas pelo PME, finalmente, o próprio corpo do Plano que discrimina níveis, diretrizes, objetivos e metas a serem alcançados pela administração municipal no campo educativo. ${ }^{5}$

projeto, portanto, contou com diferentes autores: o executivo, o CME e coletivos compostos diversificadamente, como o Fórum e o Congresso Municipal de Educação.

\section{Da justificativa, do projeto de lei e do parecer do Conselho Justificativa}

A justificativa é o espaço dedicado à manifestação do discurso oficial, do Executivo, único lugar em que é possível - ao menos em tese - a Prefeitura manifestar-se política e ideologicamente. É um texto que faz uma retomada do lugar do PME no conjunto da legislação de ensino e apresenta a visão do poder instituído. Ou seja, inicia refazendo a trajetória legal que levou à instituição do PME, retirando seus fundamentos da Constituição Federal de 1934, das Constituições Federais de 1946, 1967 e 1988, no que consagraram a necessidade de formulação de um plano educacional. Fica nítida a referência à "idéia de Plano, instituído em Lei, estabelecendo

\footnotetext{
${ }^{3}$ O Plano Municipal de Educação será anotado aqui como PME, peça integrante do Projeto de Lei do Executivo 62/2004 (PORTO ALEGRE, 2004c), apesar de sua paginação ser independente, por se tratar de um anexo processual. A numeração de páginas, portanto é do próprio PME, e não do processo. Quando o texto se referir ao PLE, as páginas indicadas são as do processo.

${ }^{4}$ A administração petista iniciou-se em 1989, com a eleição de Olívio Dutra, e após, sucessivamente Raul Pont, Tarso Genro, que se afastou do cargo para concorrer ao governo do Estado. O mandato de Tarso Genro foi completado pelo vice-prefeito João Verle.

${ }^{5}$ Com a ascensão, em 2005, do novo Prefeito, José Fogaça, o projeto foi retirado da pauta, encontrando-se desde então para estudos na Secretaria Municipal da Educação.
} 
seu prazo de duração, finalidades de articulação e desenvolvimento do ensino em seus diversos níveis e integração das ações do poder público" (PORTO ALEGRE, 2004c, p. 1). Para defender o projeto, o executivo utiliza vários argumentos, mas a argumentação de fundo é de que se trata de um projeto de lei sistêmico, pois completa e sistematiza, em nível local, a legislação anterior. A referência de base é a legislação que, desde 1996, organiza em âmbito nacional o sistema de ensino, a saber, a Lei de Diretrizes e Bases da Educação (BRASIL, 1996) e o Plano Nacional de Educação (BRASIL, 2001). Além da inserção do PME na dimensão de documento legal, vinculado à visão de sistema, ou que se pretende articulada e demandada pelas ordenações legais de âmbito nacional, também há a preocupação em apontar seus vínculos com a Lei Orgânica do Município de Porto Alegre, as Leis que criam, respectivamente, o Conselho Municipal de Educação e o Sistema Municipal de Ensino (de 1991 e 1998), já que todas fazem referência ao PME. Nessa dimensão a visão de sistema reaparece na defesa do documento base do plano, que "recuperou os compromissos e diretrizes emanadas do debate educacional dos Congressos da Cidade, dos Congressos Municipais de educação, dos planos educacional e plurianual, como também da legislação pertinente" (PORTO ALEGRE, 2004c, p. 3).

A segunda característica que emerge da justificativa do Prefeito João Verle é a defesa de que o plano é produto do processo democrático e participativo de gestão. Há que esclarecer que, em 4 de junho de 2004 é publicado, no Diário Oficial de Porto Alegre, o Regimento Interno do Fórum do Plano Municipal de Educação. Composto por 45 entidades representativas da sociedade civil e órgãos do poder público, teve o objetivo de elaborar de fato o Plano, "de forma democrática e participativa" (PORTO ALEGRE, 2004d). A divisão de poder é clara: de um lado, o Conselho Municipal de Educação e a Secretaria Municipal de Educação (SMED), com a responsabilidade de "impulsionar" o processo de construção do PME; por outro, as 45 entidades representativas da sociedade civil e órgãos do poder público, "com o compromisso de viabilizar a elaboração do referido plano" (PORTO ALEGRE, 2004c, p. 3). O Regimento estabelece assim a hierarquia e autonomia relativa de cada instância: o Plano é produto do Fórum para o Sistema Municipal de Ensino "e responsabilizou-se pelo planejamento das etapas e pela metodologia de sua construção, buscando reunir, em torno deste objetivo, o maior grau de participação da população da cidade, para legitimar o Plano em elaboração." (PORTO ALEGRE, 2004c, p. 3). O modo de construção do Plano, a análise do nível discursivo e os sujeitos que revela será o indicador a ser adotado da veracidade desta proposição.

A terceira característica é a idéia de que o plano se coloca no horizonte democrático porque é elaborado à imagem e semelhança do processo legislativo. $\bigcirc$ documento base é assim, no período de agosto a novembro 2004 constituído a partir de 3 mesas de formação, grupos temáticos de trabalho organizados para discutir as questões relativas à gestão democrática de ensino, ao financiamento da educação e à educação básica como direito dos cidadãos e cidadãs, temas que foram objeto de sete encontros temáticos e outros espaços de reunião que possibilitaram a construção

\footnotetext{
${ }^{6}$ Neste trabalho optamos por referirmo-nos ao projeto relacionando-o a gestão do prefeito em exercício, uma vez que a troca de chefes do poder executivo é de importância para a interpretação da tramitação do projeto de lei e reveladora dos interesses em conflito por ocasião da sua promulgação ou não.
} 
de Emendas apresentadas pelas entidades que compõem o Fórum do Plano Municipal de Educação (FPME). $\bigcirc$ equivalente da assembléia ou do plenário do parlamento é o Congresso Municipal de Educação, que é a "instância legitimamente constituída no âmbito do Sistema Municipal de Ensino para a definição das políticas educacionais" (PORTO ALEGRE, 2004c, p. 2). Segundo o Prefeito, tais reuniões envolveram entre 1.500 e 2.500 pessoas.

A dimensão democrática também é assegurada pelas formas de divulgação. $\bigcirc$ documento assegura que o processo de divulgação foi amplo, já que

foram encaminhadas a todas entidades/órgãos componentes do FPME, correspondências, folderes e cartazes referentes às várias etapas de construção do Plano, bem como esclarecimento quanto a possibilidade de credenciamento, com direito a voz e voto no Congresso, de todo o cidadão e cidadã que tivesse participado de, no mínimo, um dos espaços acima mencionados (PORTO ALEGRE, 2004c, p. 4).

Ponto importante do processo de democratização do Plano ocorre com a realização do III Congresso Municipal de Educação, de 26 a 30 de novembro 2004, que transforma o Fórum do PME em entidade permanente de acompanhamento do processo de votação na Câmara Municipal de Porto Alegre, com a função de verificar sua implementação e realizar sua avaliação.

Da leitura da justificativa, fica claro que as premissas do processo são também seus principais problemas. $\bigcirc$ primeiro é a visão de sistema que defende. É uma visão finalista, uma vez que se supõe a última etapa legal referida a um processo que iniciou na instância federal e tem inspiração na década de 30. Ao contrário, sua iniciativa poderia dar mais valor ao seu momento histórico, concebida como o instrumento específico de uma política educacional, particularmente datada, brotando de grupos e de movimentos sociais aos quais, com grande esforço articulou.

O segundo é a visão de democracia que defende, iá que não é a articulação de um grande número de entidades (45 ao todo) que revela a participação, mas a qualidade do debate: como avaliar, no seu conjunto, a freqüência e a qualidade da participação de cada entidade? em que momento do processo, após consolidada a lei, de fato as entidades se reapropriaram do instrumento legal? A simples presença de entidades em reuniões corresponde a visão simplista de participação como "solução de todos os males", quando ela é de fato um processo, construída coletivamente - voltaremos adiante a este ponto.

Finalmente, há que considerar que pode induzir a erros a idéia de que basta seguir as regras do processo legislativo convencional para se alcançar os objetivos da conquista de um processo democrático. $\bigcirc$ exemplo é o que ocorre hoje. Em novo período de governo, tendo outro partido assumido o poder municipal, seguindo as mesmas regras ou "narrativas processuais", o processo foi "retirado" de pauta pelo atual chefe do executivo, o Prefeito José Fogaça. 


\section{O Projeto de Lei}

De todas as peças, surpreende que o projeto de Lei é a menor delas. O paradoxo é devido ao fato de que seu objetivo é apenas "instituir" o Plano Municipal de Educação que foi produto das discussões do Fórum do Plano Municipal de Educação. São ao todo apenas seis artigos, à semelhança da Lei do Plano Nacional de Educação. O primeiro declara aprovado o plano; o segundo, as instituições que procederão as avaliações periódicas da sua implementação; o terceiro, as instituições que compõem o Fórum - entre elas, a Câmara Municipal de Porto Alegre ${ }^{7}$; quarto, a definição do Plano Plurianual e da Lei de Diretrizes Orçamentárias como instrumentos de "suporte"; o quinto, o papel de todos os poderes e órgãos envolvidos para sua divulgação e realização.

A principal característica do projeto de Lei é instituir o princípio da duração ${ }^{8}$. É ali que lemos que é uma lei prevista para durar 10 anos. $\bigcirc$ objetivo da longa temporalidade é proporcionar uma política duradoura no campo educacional. Isto é essencial porque o PME é um instrumento de estado e não de governo. Ele colabora para que as políticas educacionais tenham continuidade para além dos governos. Por ter sido um documento construído por entidades de classe, a longa duração ameniza um sempre presente temor de que futuros governos reapropriassem o plano para $\mathrm{si}^{9}$.

projeto de lei estabelece uma série de instituições vinculadas para a implementação das diretrizes, mas não aponta como deverão ser mediadas as relações - o que sugere a necessidade de nova lei regulamentando-a. Ao deliberar que é a Câmara Municipal que deve apreciar relatórios e verificar medidas para sua correção, estabeleceu um critério que não é isento de problemas. Se, por um lado, é importante o legislativo participar do processo de constituição do Fórum e atuar no campo de sua competência, de fato sua participação como instância de fiscalização pode sugerir o conflito de duas instâncias de representação: de um lado, o fórum, que participou do momento de organização da proposta; de outro, a Câmara, que assume o processo que foi do fórum. A pergunta é: quem é competente para acompanhar o processo em todas as suas fases e desdobramentos?

A idéia de competência e responsabilidades do legislativo é um problema desde o início do processo. Recordamos o que aconteceu. Quando chegou à Câmara Municipal a convocatória de participação do Legislativo no Fórum, cabia à Presidência e à Direção Geral da Casa a incumbência de indicar quem participaria. Havia dúvidas na Casa sobre quem indicar. Inicialmente era o Presidente da Casa, e após, o Presidente da Comissão de Educação, Cultura e Esportes os indicados para participar, mas de fato, oficialmente nada aconteceu. Nenhum ato formalizou a indicação do

\footnotetext{
${ }^{7}$ As demais são: Associação dos Trabalhadores em Educação do Município de Porto Alegre (ATEMPA) Associação Gaúcha de Apoio às Altas Habilidades/Superdotação (AGAASHD);Associação dos Supervisores em Educação do Estado do Rio Grande do Sul (ASSERS), Centro dos Professores do Estado do Rio Grande do Sul (CPERGS), Fórum do Conselho Municipal de Educação, Secretaria Municipal de Educação de Porto Alegre, Conselho Municipal de Porto Alegre,Associação dos Inspetores de Educação do Estado do Rio Grande do Sul(AIERGS) e Associação dos Orientadores Educacionais do Rio Grande do Sul (AOERGS).

${ }^{8}$ No que o PME se vincula e submete ao PNE.

${ }^{9}$ Foi o que ocorreu por ocasião da discussão e aprovação do Plano Nacional de Educação, onde uma proposta da sociedade foi substituída por uma proposta gestada em gabinete.
} 
representante da Câmara Municipal, o que não significa que não houvesse participantes do legislativo. Alguns vereadores e técnicos da Câmara acompanharam o processo, de forma individual e não representativa. Quer dizer, a instituição omitiu-se de acompanhar o processo pela dificuldade de indicar o seu representante. Instala-se assim uma questão: se pouco participou de sua formulação, a Câmara Municipal terá condições de acompanhar sua execução? Mais: qual é seu campo de interferência da Câmara Legislativa no projeto: na lei de 6 artigos ou no Plano como um todo?

Por outro lado o texto do projeto de lei atribui lugar secundário ao que deveria ser essencial. A atuação direta sobre as políticas de financiamento através do Plano Plurianual e a Lei de Diretrizes Orçamentárias são, de fato, um aspecto central e não secundário da lei e são instrumentos fundamentais para a execução do PME. A razão é que os estudiosos, como Nalu Farenzena e Vidal Didonet ${ }^{10}$, já apontaram que conceber um plano sem aporte de novos recursos é condená-lo ao fracasso logo de saída. A lei deve indicar o ponto de conexão, ao final, entre o que o Plano indica e o que as leis que regem a matéria orçamentária farão. Este é um campo que fica aberto à atuação do legislador: poderá o plano, no momento de sua avaliação pelo poder legislativo emendar o projeto de lei naquilo que não foi feito antes pelo Fórum? Do ponto de vista da matéria legislativa em geral, como é o caso das propostas de Orçamento e LDO, a resposta é sim. Entretanto, no caso em questão o assunto não é isento de problemas. ${ }^{11}$

Assim, o projeto de Lei não é o Plano. Mas ele cria os limites e possibilidades de atuação para todas as entidades envolvidas e dá o horizonte para sua execução: ele aponta para o cenário político e econômico, mas não pode exercer a força de submeter o conteúdo e objetivos do PME.

\section{O Parecer 8/2004 do CME}

Conselho Municipal de Educação de Porto Alegre, nos termos da prerrogativa conferida pelo artigo 10, alínea " $a$ ", da Lei n 8.198 (PORTO ALEGRE, 1998), de 26 de agosto de 1998 e artigo $6^{\circ}$., da Lei $n^{\circ} 248$, de 23 de janeiro de 1991 (PORTO ALEGRE, 1991), tem a obrigação de dar parecer prévio sobre o PME, analisando três peças: o histórico do processo de construção do plano, o Regimento Interno do Fórum e o Plano Municipal propriamente dito.

A análise justaposta pelo CME tem três características. A primeira é que seu texto realiza a definição do processo. Tanto na análise do histórico, quanto do regimento ou do Plano, a primeira preocupação dos conselheiros é com a definição dos termos e procedimentos empregados. Seja pela retomada do processo histórico, na definição das entidades e seu objetivo, seja no que significa o Fórum como representante da sociedade civil e educacional, seja na definição do regimento interno como campo da formulação das políticas públicas. A característica dominante do Parecer do CME afigura-se como uma

\footnotetext{
${ }^{10}$ Didonet, em palestra realizada na Unisinos, 2003.

11 O processo já é conhecido em nível federal e estadual. Como os procedimentos que levam a elaboração do PME são lentos, regra geral as leis que regem a matéria orçamentária já encontram-se elaboradas. É exatamente esse o caso, pois a elaboração da Lei do Plano Plurianual que rege o governo José Fogaça foi aprovada no último ano do governo João Verle, sem considerar as reivindicações do PME.
} 
certa obsessão pela clareza. Esta característica associa-se à preocupação de revelar a legitimidade do movimento que levou à elaboração do PME. Parece-nos, entretanto que essa questão permanecia clara para seus participantes e organizadores desde seu princípio. Assim, o parecer não aborda as tensões e os conflitos por ocasião da constituição do plano e de seu regulamento, anulando, pela escrita, o movimento intenso de produção da discussão sobre os rumos da educação municipal.

A segunda característica é que o Parecer realiza uma fenomenologia do Fórum. Ele não se arrisca a analisar, contenta-se em descrever. A descrição do projeto que realiza é retomada na primeira parte do oficio do prefeito, num de seus temas, o da longa jornada de sua elaboração. Retoma também as finalidades do Fórum naquilo que está explícito nos documentos, especialmente em seu Regimento Interno, em seu artigo $5^{\circ}$. $\bigcirc$ efeito é consagrar aquilo que pode ser objeto de polêmica; tal como a dúvida de se é representativo neste processo o direito a voto daqueles que tenham tido "presença de, no mínimo, uma reunião/encontro no âmbito do sistema municipal de ensino" Esta defesa é problemática, pois como a primeira, retira do leitor a capacidade de perceber os conflitos e contradições ao longo do processo e termina por apresentar o proposto como o realizado, o que era desejado como o acontecido. Há ainda uma certa ambigüidade entre os termos "objetivo" e "processo", o que também contribui para imunizar o processo de eventuais críticas e críticos. È o que nos recorda um dos poucos contatos que tivemos ao longo do processo com membros de entidades de classe, preocupados com o caráter do direito à voto para participantes de uma reunião. Além disso, a dúvida formulada por entidades que compunham o Fórum era se o documento não se estava transformando em afirmação da política do partido no governo. Algumas entidades, em caso de futura derrota do partido (PT), temiam que a identidade exagerada a um programa de governo, contribuísse para atravancar o processo de instalação do PME. A retirada do processo da pauta, no ano seguinte, parece confirmar esta suspeita.

A terceira característica é o legalismo do parecer. A parte final, que trata da análise do PME, se contenta em confirmar a série de documentos legais em que se baseia e fundamenta; ela, em nenhum momento, de fato, avalia, critica ou dá significado ao conteúdo do PME e, nem ao menos, aponta sua necessária repercussão orçamentária e em termos de Plano Plurianual de Investimentos, considerações que devem ser levantadas no que se refere ao financiamento do plano e talvez um dos mais importantes temas abordados ao longo dos encontros. Essa ausência é notável, uma vez que o próprio parecer defende que o plano

tem necessariamente uma dimensão política e outra técnica. $\mathrm{Na}$ dimensão técnica, devem prever avanços e alternativas de solução de déficits educacionais com base no levantamento de dados e na elaboração de um diagnostico consistente das realidades municipais e estaduais. Na dimensão política, deve sistematizar ações a ser (sic) desencadeadas com base em diretrizes, prioridades e metas, democraticamente definidas, que ampliem seu potencial de organização prospectiva, de forma a ir concretizando o direito de todos à educação (PORTO ALEGRE, 2004c, p. 16). 
Quer dizer, o CME manifesta-se a favor por que a proposta de PME é legal, e seu parecer é "favorável ao disposto no Plano Municipal de Educação de Porto Alegre" sem nenhuma análise real de seu conteúdo, já que a exposição de sua estrutura básica - itens 3.4.2 a 3.4.7 - não tem condições de ser considerada uma avaliação dos temas do plano, apenas sua descrição. É interessante, entretanto, que, mesmo sem uma indicação explicita à questão orçamentária ou ao seu conteúdo, o parecer do CME foi suficientemente avançado para apostar no poder legislativo para "aprofundar a discussão sobre o Plano Municipal de Educação", mas no limite de um espaço onde "reconheça o conteúdo democraticamente construído pela sociedade civil participante de sua elaboração".

Esta "aposta no poder legislativo" também não deixa de impor questionamentos, alguns dos quais anunciados em linhas anteriores deste texto. É facultado ao legislativo alterar o conteúdo do plano ou apenas do projeto de lei do executivo? Nos termos em que é apresentado, o Parecer não induz a um conflito de representação? Afinal, são os 47 representantes, o fórum exclusivo de elaboração do Plano ou o legislativo, como fórum representativo da cidade que pode, retomar o debate e usar dos procedimentos legislativos de praxe (emendar, substituir), no conteúdo do Plano? As decisões do Fórum podem ser subordinadas a uma segunda instância de representação, o parlamento?

\section{O Plano Municipal de Educação Análise da "introdução"}

A introdução do plano apresenta o histórico das iniciativas congêneres e é a peça que servirá de base tanto para a justificativa do projeto pelo Prefeito quanto para o parecer do $C M E$, porque ali são retomados todos os instrumentos legais que apontam na direção da construção do PME. Na realidade, as peças anteriores são resumos do conteúdo aqui exposto.

A característica que chama a atenção, e constitui a conclusão desta primeira parte, é a de "transliteração", a aplicação das conclusões clássicas de Vidal Didonet ao PME. Como se sabe, Didonet (BRASIL, 2000) é autor da apresentação de uma das versões disponíveis do PNE. Em um belo texto, lista as características do PNE (é plano de Estado e não de governo, é aprovado por lei, é articulado com as demais esferas), e sua justificativa propõe caracterizar o plano municipal à maneira do plano nacional. Apresenta-se aí, de maneira discreta, o primeiro pressuposto do plano: o de que um plano municipal é um "cantinho de obras" do plano nacional, o que quer dizer, que funciona como o plano nacional, do qual é puro simulacro.

Este não é um detalhe menor. Se considerarmos a abordagem cognitiva das políticas públicas, tal como define Muller e Surel (2002), deve-se pensar a elaboração do Plano Municipal de Educação a partir das matrizes normativas e culturais que o engendram. Nesse caso, se o PME for considerado como um "sistema de interpretação" - da realidade educacional local, do envolvimento dos atores no processo - o peso dos valores e concepção dos atores, o ângulo de abordagem que escolhem para construir seus instrumentos é revelador dos modos de ação do estado. Ou seja, 
tal detalhe do processo parece indicar que o Plano Nacional de Educação (PNE) se constitui no paradigma a partir do qual é construído o Plano Municipal de Educação. Quer dizer, que a estrutura e natureza do Plano Nacional definem o universo a partir do qual se circunscreve o PME. Funcionando como um tipo de "matriz cognitiva", o PNE é o instrumento normativo que determina as considerações práticas da elaboração do PME naquilo que se pode chamar de "lógica de sentido" (DELEUZE, 2002). A pergunta é: que tipo de tomada da palavra (produção de sentido) o PME revela? Que tipo de tomada de poder (estruturação de um campo de forças) ele constitui? Estas questões contribuem para a análise e problematização do Plano: seriam os participantes de sua elaboração totalmente livres em suas escolhas (tese voluntarista) ou seriam antes suas escolhas determinadas (tese estruturalista) por algo externo aos atores do processo? Para Muller e Sorel (2002, p. 51):

A abordagem cognitiva, de seu lado, repousa sobre a idéia que uma política pública opera como um vasto processo de interpretação do mundo, ao longo do qual, pouco a pouco, uma visão do mundo vai impor-se, vai ser aceita,depois de reconhecida como "verdadeira" pela maioria dos atores do setor, porque ela permite aos atores compreender as transformações de seu contexto, oferecendo-Ihes um conjunto de relações e interpretações causais que thes permitem decodificar, decifrar os acontecimentos com os quais são confrontados.

\section{Análise do "Perfil do município e diagnóstico da educação"}

A primeira característica que emerge na construção da proposta é sua autoria. Afinal, o PME espelha a interpretação do Fórum ou do Poder Executivo? Esta parece ser a maior ambigüidade da narrativa do Plano. A sua primeira parte é reveladora disto, ao ser composta por uma série de dados que têm como objetivo apresentar a realidade do ensino no município. Ela começa com a importância de falar da história da cidade, "que apresenta avanços na construção de políticas democráticas". A característica principal desta parte é sua construção irregular. Há uma pequena digressão com relação à colonização de Porto Alegre para, em seguida, serem apresentados dados relativos à geografia do tipo "zona temperada e tropical" e os referentes à presença da população por cor, a presença kaigang e guarani.

Ao leitor atento, o primeiro questionamento é o significado destas informações para o conjunto do projeto, já que nada tratam da história da educação na capital, nem da evolução do sistema de ensino. Elas sugerem a idéia da existência de um escritor anônimo, mais preocupado em fundamentar, com estatísticas, a introdução de um texto e de defender o projeto em andamento, perdido frente às informações que tem por obrigação apresentar à comunidade. É sutil a linha que separa a evolução política da educação da cidade da atuação do atores envolvidos e do partido, há 16 anos à frente da Prefeitura. Embora negando pode-se identificar no texto uma dimensão de consolidação do PME como o projeto do governo, como no trecho que segue:

A promoção do desenvolvimento no município de Porto Alegre vem avançando ao longo das duas últimas décadas para o prin- 
cípio do cumprimento das funções sociais da cidade, garantindo políticas baseadas na gestão democrática, participativa e descentralizada, bem como a promoção da qualidade de vida e do meio ambiente, reduzindo as desigualdades e a exclusão social. Para tanto, o poder público e a sociedade civil empenharam-se na criação e no fortalecimento de mecanismo de participação, tais como os Conselhos Municipais e o processo do orçamento participativo que, em seus dezesseis anos de existência, tornou-se um modelo de gestão sócio-estatal que permite o controle do orçamento público pela sociedade civil. Este processo está organizado a partir de divisão geográfica da cidade em dezesseis regiões, além da realização de seis plenárias temáticas definidoras de políticas para toda a cidade (PORTO ALEGRE, 2004b, p. 8).

Ora, o que queremos apontar não é uma crítica a políticas de governo em Porto Alegre, mas que discursos o PME sustenta na realidade. A passagem citada se justificaria se o Orçamento Participativo ou seus representantes fossem membros do Fórum ou se o Orçamento Participativo fosse instância de decisão sobre o Plano. Entretanto, o texto do Plano revela não apenas a dificuldade de redação do documento, mas a confusão das prerrogativas do campo educativo com o político que usam do Plano para se expressar.

A primeira informação de relevância para o campo educativo surge páginas após, com a apresentação dos indicadores do Índice de Desenvolvimento Humano (IDH) para Porto Alegre, apresentando o importante avanço de 0,907 para 0,951, no período que vai de 1991 a 2000. Os autores concluem que:

Segundo o Programa das Nações Unidas para o Desenvolvimento (PNDU), o município está entre as regiões consideradas de alto desenvolvimento humano (IDH maior que 0,8). Diz ainda que em relação a outros municípios do Brasil, Porto Alegre ocupa a $9^{a}$. posição e em relação ao demais municípios do estado, ocupa a $2^{a}$. posição" (PORTO ALEGRE, 2004b, p. 9).

Continua o texto afirmando que a segunda maior variável que contribui no IDH$M$ de Porto Alegre é a Educação, com 36,1\%.

O segundo dado importante trazido pelo Plano é a população total na faixa escolar da cidade. Segundo gráfico elaborado pelo Conselho Municipal de Porto Alegre, a partir dos dados do Censo Demográfico de 1991, do Instituto Brasileiro de Geografia e Estatística (IBGE), Porto Alegre possui 152.510 crianças na faixa etária de 0 a 6 anos, que devem ser atendidas pela Educação Infantil e 184.673 crianças na faixa dos 7 aos 14 anos a serem incluídas na Educação Básica, modalidade Ensino Fundamental. Retomando estudo de Costa (2003, p. 9) indica que a proporção da população porto-alegrense nos grupos de idade declinou e que "há em Porto Alegre, 45,8 crianças, adolescentes e idosos para cada 100 pessoas em idade produtiva" (PORTO ALEGRE, 2004b, p. 10). 
Os dados reforçam ideologicamente a valorização das ações políticas do governo, uma vez que figura, na página seguinte, sua distribuição pelas regiões do Orçamento Participativo. Um efeito positivo desta segmentação é a apresentação de tabela que privilegia os bairros mais pobres da cidade (Arquipélago, Bom Jesus, Lomba do Pinheiro, Mário Quintana, Restinga e Chapéu do Sol) discriminando sua população infanto-juvenil, para demonstrar que esta já ultrapassa o percentual de $40 \%$, chegando, em certos casos a até $45 \%$. A informação é transcrição do Relatório de Indicadores Sociais de Porto Alegre, datado de 2002.

Um dos fatores positivos do PME, portanto, é a síntese que realiza dos dados educacionais disponíveis. $\bigcirc$ Relatório retoma os argumentos de Costa reiterando que

no período 1991-2000, a escolaridade média das pessoas responsáveis pelos domicílios em Porto Alegre elevou-se de 8,3 anos de estudo em 1991 para 9,1 anos de estudo em 2000. Em relação ao gênero, a escolaridade média dos homens responsáveis pelos domicílios cresceu de 8,6 anos de estudo em 1991 para 9,3 anos em 2000, ao passo que as mulheres chefes de família ampliaram sua escolaridade de 7,7 anos para 8,7 anos de estudo no mesmo período (PORTO ALEGRE, 2004b, p. 20).

Estes dados servem para demonstrar que o objetivo de democratizar a educação foi atingido, já que "o analfabetismo foi praticamente erradicado da capital, estando restrito às pessoas mais velhas, principalmente às mulheres e aos segmentos empobrecidos da população" (PORTO ALEGRE, 2004b, p. 26). O estudo de Costa (2003) é, contudo uma análise da própria Prefeitura Municipal, elaborada pela Secretaria de Governo Municipal, Direitos Humanos e Segurança Urbana, publicado em 2003, e que é retomado nas metas e diretrizes do PME.

A importância do cruzamento de fontes é respeitada no PME com a utilização dos dados do Mapa do Analfabetismo no Brasil (INEP, 2003). Essa publicação do Instituto Nacional de Estudos e Pesquisas Educacionais (INEP) registra Porto Alegre ocupando a terceira posição entre os dez primeiros municípios cuja população de 15 anos ou mais tem, em média, os maiores índices de anos de estudo em 2000. A capital só perde para Niterói, Florianópolis e Vitória e tem índices superiores à Curitiba e Rio de Janeiro, respectivamente na $9^{a}$. e $10^{a}$. posição. $\bigcirc$ capítulo referente ao "Perfil do município e diagnóstico da educação" conclui com "a intenção de propor uma reflexão sobre as políticas na área de educação [...] que deve priorizar a elevação global do nível de escolaridade da população, a melhoria na qualidade do ensino, a redução das desigualdades sociais no tocante ao acesso e permanência com sucesso na educação pública" (PORTO ALEGRE, 2004b, p. 12), entre outros aspectos.

A avaliação deste capítulo permite levantar alguns temas de debate: seus autores tinham ou não idéia de onde começar a narrativa do Plano ao falar de Porto Alegre? $\bigcirc$ texto construído perde-se ou não em dados sem contexto? Os dados educacionais surgem para demonstrar a evolução positiva da educação em Porto Alegre? Entretanto quaisquer que sejam nossas respostas a estas questões, uma característica é marcante, 
a de magnetizar os dados: ou seja, a apresentação dos resultados educacionais, mais do que revelar a ação da Prefeitura, revela a intenção de atrair para si as conseqüências de um processo de ensino que inclui as ações de iniciativa do Governo do Estado e que tem em Porto Alegre sua sede. Talvez ao ceder a limitação de trabalhar com dados de terceiros e usar, na maior parte do texto, dados produzidos pelo próprio executivo, enseje mais pesquisa sobre o público atendido pela rede municipal de ensino, proporcionalmente ao total de habitantes, o que poderia oferecer dados com mais credibilidade da política educacional do município e seus efeitos na elevação do nível de educação, proporcionalmente à sua rede. Este aspecto é ausente e é fundamental.

\section{Análise dos "Temas básicos da educação"}

A estratégia utilizada para diferenciar o Plano Municipal de Educação do Plano Nacional foi a separação da teoria e da prática. Enquanto no Plano Nacional, o diagnóstico dos níveis de ensino é seguido pela descrição dos objetivos e metas, o PME os separa em capítulos distintos. A conseqüência é que, se este formato permite acrescentar tópicos e seguir reflexões que não existiriam se fosse seguido ou o modelo proposto pela UNDIME ou o modelo proposto pelo MEC 12 resulta uma distância muito grande entre o diagnóstico e as metas. $\bigcirc$ efeito é que o texto em sua seqüência não favorece a avaliação das metas, se elas atendem às demandas, o que é perigoso para um plano de educação, que deve, ao contrário, encaixar suas peças num todo coerente. Quer dizer, o plano defende a idéia de sistema: ele é vinculado externamente às demais legislações de ensino; mas isto não é suficiente para que ele seja integrado, como peça pedagógica. Ao contrário, é na ausência de unidade entre a parte introdutória e as diretrizes e metas que ele nega a idéia de sistema.

Os pontos de análise são escolhidos com propriedade: Sistema Municipal de Educação, Gestão Democrática e Financiamento da Educação. O problema é saber se eles estão aí para fundamentar as diretrizes e metas ou servir de justificativa para um suposto "Executivo Oculto." 13 Verdadeiro sujeito desta parte do Plano, ele se sobrepõe aos múltiplos discursos por que o uniformiza. $\bigcirc$ texto endereça para a idéia de que a política desejável é a atual política, a gestão desejável, a gestão do atual governo, o financiamento "possível" o financiamento realizado pela Prefeitura. Como diferenciar um e outro sujeito de discurso neste plano?

Vejamos o tópico da análise do tema Sistema Municipal de Ensino. É um dos temas mais importantes, mas uma leitura atenta em relação ao projeto como um todo parece revelar que foi feito "para cumprir" formalidades, já que não ultrapassa uma página. Revela que as origens da criação do Sistema Municipal de Ensino de Porto Alegre em 1998, pela Lei Municipal 8.198, ${ }^{14}$ realiza um retrospecto até os anos 80 nas proposições de revigorar o sistema federativo e a opção do município de Porto Alegre em ter seu próprio sistema, que "significou grande avanço na autonomia pedagógica e administrativa das mantenedoras e

\footnotetext{
12 A proposta da UNDIME está disponível em: <www.undime.org.br> e do MEC em: <www.mec.gov.br>. São peças técnicas de referência para os municípios elaborarem seus respectivos Planos.

13 Foi Michel Pêcheux (1995), da escola pós-marxista de análise de discurso que em sua obra "Semântica e discurso", chamou a atenção para as relações entre ideologia e linguagem, colocando em discussão a noção de sujeito oculto. 14 Porto Alegre, 1998.
} 
das instituições de ensino." 15 Afirma que a intenção de seus autores é "encontrar uma nova lógica de planejamento e financiamento da educação pública, propiciando maior flexibilização e autonomia local." 16 efeito é que "a municipalização da educação é o caminho para atender as novas demandas e aos novos contextos educacionais." 17 É a Lei do Sistema de Ensino que define o Conselho Municipal de Educação como órgão normalizador e a SMED, como órgão administrador. Aqui surge uma informação que já poderia ter sido anunciada na parte anterior, a da composição do sistema:

O Sistema Municipal de Ensino é integrado pelas instituições de educação infantil, de ensino médio e fundamental mantidas pelo poder publico municipal, num total de 92 escolas, e pelas instituições de educação infantil da rede privada, que não estejam associadas à outro nível de ensino, cujo cadastro, no Serviço de Regulamentação da Educação Infantil da SMED (SEREEI), registra, em 2004, um total de 538 instituições, sendo 405 creches e/ou préescolas e 133 creches comunitárias conveniadas com a Prefeitura Municipal de Porto Alegre (PORTO ALEGRE , 2004b, p. 13).

A segunda parte trata da Gestão Democrática. A idéia defendida é que a democratização da gestão educacional é etapa necessária da democratização da sociedade. Princípio constitucional, definida no sentido amplo como "pleno acesso de todos os cidadãos à educação" (PORTO ALEGRE, 2004b, p. 13), o é no sentido estrito que revela seu caráter progressista, quando é definida como "garantia de acesso, permanência e sucesso, com a conclusão dos estudos, em instituições de ensino." 18 Aqui, o motivo de polêmica é a idéia de sucesso, face às críticas ao sistema por ciclos na rede pública. ${ }^{19}$

Por outro lado, o detalhe importante do conceito de gestão, tal como é apresentado no PME, é que a população deve ter "participação na elaboração das políticas educacionais". Quer dizer, o conceito de gestão democrática não se reduz a gestão administrativa - como organizar o currículo e os objetivos educacionais - mas vai além, pois inclui a dimensão das políticas educacionais como cenário da gestão democrática, reconhecendo aos sujeitos ligados à educação o direito de partilhar, com o Estado, a formulação de políticas públicas.

Torna-se premente a necessidade de garantir a participação dos atores sociais envolvidos na gestão, através de espaços de discussão, deliberação e avaliação do currículo (entendido de forma ampla) das instituições de ensino e, também, na esfera macro, a participação na elaboração das políticas educacionais [...] participação social nos processos de reflexão, decisão e avaliação do conjunto das políticas educacionais e das ações pedagógicas (PORTO ALEGRE, 2004b, p. 13).

15 lbid., p. 11.

16 lbid., p. 12.

17 lbid., p. 13.

18 Porto Alegre, 2004b, p. 13.

19 A retirada do projeto do debate no Legislativo, ocorrida no inicio do ano legislativo de 2005, fase de constituição do novo secretariado municipal agora, de outro partido, é uma forma de expressão de tais críticas. Em 2004, durante o processo eleitoral partidos de oposição ao PT promoveram discussões e avaliação do sistema educativo da administração anterior, focando especialmente o sistema por ciclos. Relembrar este processo revela a grande resistência do novo governo em relação às propostas do governo anterior. 
capítulo encerra-se com tópicos que, novamente, ficam a meio caminho entre a descrição das políticas prevista para o PME e a retranscrição das ações do poder executivo e, com isso, reforço das políticas do governo sob o qual a proposta foi elaborada. É o caso da retomada do nascimento dos Conselhos Escolares na rede municipal de ensino e a descentralização dos recursos financeiros, que levaram ao Orçamento Participativo Escolar. Novamente, assepticamente, os avanços da gestão educacional são apresentados de forma homogênea e limpa de conflitos. Uma visita às escolas permite perceber que, ao contrário, os Conselhos Escolares enfrentam dificuldades no cotidiano escolar; que a descentralização de recursos financeiros foi parcial nas escolas, uma vez que alguns se ressentem do valor que é repassado. Uma coordenadora de eventos relatou: "Uma agência apresentou-me um pequeno projeto cultural para executar na escola, já que agora (no governo atual) não se vê mais a SMED na escola nem a Cultura. Sabe quanto pediram? Dois mil reais! Pô, cara, dois mil reais é o que a escola tem para seu material para o ano todo e é muito pouco, viu?"

Um tópico muito importante dentre os temas apresentados é o do Financiamento da Educação, o qual encerra a Seção "Temas básicos da educação". A primeira parte apresenta um histórico do financiamento, detalhando suas idas e vindas desde 1930, na questão da vinculação dos recursos para a educação. A segunda parte aborda, em detalhes, o financiamento da educação nos dias atuais. Descreve o funcionamento do financiamento da educação a partir das receitas de impostos, o papel do salário educação, o Fundo de Manutenção e Desenvolvimento do Ensino Fundamental e de Valorização do Magistério (FUNDEF), incorporando a avaliação e as críticas já realizadas no campo da análise de políticas educacionais, qual seja, a de que o FUNDEF "não incorporou mais recursos para a educação, uma vez que é apenas um mecanismo de redistribuição dos recursos já vinculados" (PORTO ALEGRE, 2004b, p. 15). Para o plano, isto apresenta um efeito imediato, já que "os recursos disponíveis à educação são insuficientes para dar conta das necessidades crescentes" 20 .

Uma tabela demonstra que isto decorre do fato de que a ampliação da carga tributária nacional é baseada no aumento das contribuições sociais, que não colaboram no financiamento da educação e que Estados e Municípios participam proporcionalmente pouco na receita de impostos, frente ao número de matrículas. $\bigcirc$ texto revela a expectativa de uma reforma tributária positiva para os municípios no atual governo federal.

É importante salientar que esta é a principal crítica da esquerda às políticas educacionais do ex-governo FHC. Ao longo do ano que levou à elaboração do PME (2004) , é possível identificar uma expectativa grande em relação ao governo Lula, cuja plataforma também incluiu reflexões sobre política educacional e aumento de recursos para a educação Entretanto, é de se questionar se os conflitos hoje vistos entre o que o governo prometeu e o que vem realizando não se estendem ao campo educativo. A reforma do FUNDEB é um deles. A análise de conjuntura política que o tema exige envolve não apenas a interpretação das políticas públicas locais como

20 Porto Alegre, 2004b, p. 14. 
também seu modo de relacionamento com políticas nacionais. Enquanto o PME era construído, o Partido dos Trabalhadores era a base do governo municipal e as entidades participantes possuíam identificação com a esquerda e expectativas para o governo federal. Com as sucessivas trocas de governo (ascensão de Lula em nível federal e após, a de José Fogaça, em nível municipal), representantes de interesses diversos, novos conflitos de difícil assimilação foram sendo gerados. Por isso hoje, entres os membros das instituições que apoiaram a formulação do Plano ainda sob o governo municipal de João Verle, pôde ser observada a frustração por terem participado de uma proposta que chega, agora, a um ano de interrupção. Ao mesmo tempo, a descrença, em nível federal, sugere que os mesmos militantes de organizações se sentem frustrados e sem legitimidade de exigir, como representantes de esquerda, seus direitos pela execução do PME. A discussão está parada.

A expectativa frustrada de uma reforma tributária favorável aos municípios, que se depreende do documento, sugere que era mais fácil criticar a política de financiamento quando a esquerda era oposição; mas é mais difícil manter a crítica quando a esquerda assume o governo em nível nacional (em que prometia fazer e não faz) ou quando a direita assume o governo local (em que prometia pouco, e também não faz). É um indicador importante o fato de que, se o PME foi retirado, o mesmo não se pode dizer do Plano Plurianual, recentemente encaminhado à Câmara Municipal. Quer dizer, enquanto o PME aguarda decisões políticas, o Plano Plurianual e, logo após, a Lei do Orçamento, continua sua trajetória à aprovação sem considerar as reivindicações do Plano. A quem isto interessa? Alguém duvida que fique mais difícil, após a aprovação desses dois documentos a conquista de avanços em termos de financiamento da educação associados às metas e objetivos do PME? Ora, o PME aponta problemas importantes que demandam esforço político e financeiro para enfrentá-los. Como situar o PME se a destinação de recursos está comprometida?

É preciso ter presente o contexto sócio-econômico no qual estas leis passaram a vigorar. A crise econômica e as transformações do mundo do trabalho, que se acentuaram nos anos 90 , fizeram crescer a demanda por educação, em todos os níveis, pois o subemprego estrutural, a queda nos níveis de renda, além de exigir um trabalhador mais qualificado, jogou um contingente de pessoas, principalmente mulheres, na busca de trabalho e renda, as quais passaram a demandar atendimento em creches (PORTO ALEGRE, 2004b, p. 16).

Ora, a complexidade do fenômeno educacional, das causas e contextos da crise de seu financiamento é uma questão essencial para os educadores. Portanto, é natural que exista aí uma competição para dar uma causalidade aos fenômenos que pareçam coerentes com sua visão de mundo. É preciso entretanto, refletir sobre que luta ocorreu para que esta narração explicativa se afirmasse? A crítica ao governo subliminarmente colocada é um diagnóstico ou faz parte de uma visão de mundo, o que exige, mais uma vez, o acompanhamento detalhado da variedade de narrações produzidas pelos diferentes atores envolvidos. A posição de um representante de entidade de classe, preocupado em aumentar os recursos para a educação é diferente de um representante da prefeitura, preocupado em fazer a receita ficar dentro do 
orçamento. Daí que o principal problema na construção de um PME democrático é não apenas realizar uma síntese, mas dar conta dos discursos concorrentes sobre um mesmo fenômeno, reunir - e não selecionar - as causas pertinentes de um problema. A razão é que cada narração determina a identidade dos diferentes atores envolvidos, que responsabilizam, de forma diversa, os responsáveis pela crise da educação.

Capítulo de financiamento ainda aborda o tema da educação do município de Porto Alegre. A primeira novidade, no campo legal, é a defesa do estabelecido pela Lei Orgânica que, avançando em termos normativos, indica que $30 \%$ da receita de impostos devem ser aplicadas em educação. $\bigcirc$ problema é que pela lógica do FUNDEF, "os valores retidos no Fundo foram maiores do que os valores que retornavam ao município de Porto Alegre. A partir de 2002 esta situação alterou-se, ou seja, os valores que retornaram ao Município foram superiores aos valores retidos" (PORTO ALEGRE, 2004b, p. 18). Ou seja, na maior parte da existência do Fundo, Porto Alegre foi prejudicada no repasse dos recursos. Há aí uma discussão interessante: o que vale é o princípio do retorno de contribuição - e daí a justiça, quem contribui mais, recebe mais, ou ao principio de solidariedade quem pode pagar mais paga pelos municípios de poucos recursos. A discussão sobre o retorno financeiro é, na verdade, uma discussão sobre os princípios do republicanismo, que também repercute no campo educativo.

PME aponta o fato de que os recursos do FUNDEF em Porto Alegre são utilizados para o pagamento de professores e o município "complementa com outros recursos o pagamento destes profissionais" o que significa que esses recursos "são insuficientes para manter o ensino fundamental" (PORTO ALEGRE, 2004b, p. 18), Tabela 10 Complementação do Município para Pagamento dos Profissionais do Ensino Fundamental). O município, em 2002, complementou em $28,77 \%$ os recursos de pagamento de professores, e no ano seguinte, em 41,42\%. E adiante, aponta:

De 1988 a 2003, a taxa de ampliação de matrículas na Rede Municipal de Ensino foi de $228 \%$, e a taxa de ampliação dos estabelecimentos escolares foi de $217 \%$.Em 1988, eram 29 estabelecimentos e 17.862 alunos; em 2004, são 92 estabelecimentos e 58.675 alunos, na educação infantil, no ensino fundamental, na Educação de Jovens e Adultos (EJA), na educação especial e ensino médio (PORTO ALEGRE, 2004b, p. 19).

dado impõe uma reflexão: é muito ou pouco esta evolução?

Para a administração municipal é muito, considerando os a valores absolutos. Por outro lado, uma pesquisa detalhada deveria apontar o percentual ano a ano, se houve anos com maior ou menor investimento municipal em termos educacionais e se imaginamos, em uma conta apenas para referência, e dividirmos o número de alunos pelo total de anos, terá um acréscimo anual de cerca de 2.500 alunos. Isto é pouco ou é muito? Em relação ao total de alunos poderá ser pouco; em relação ao que cabe à Prefeitura (tudo, uma parte?) poderá ser muito. Ou o contrário. Afigurase que os dados do PME são apresentados de forma muito rápida e não exaustiva. 
Ora, o PME não precisaria dominar todos os dados porque depende de fontes de pesquisa que lhe fogem; mas deveria ser capaz de aprofundar o significado das informações que oferece ao leitor.

A interpretação também vale para a parte que trata da Manutenção e Desenvolvimento da Educação Infantil. O PME destaca que entre 1989 e 2004 foram entregues 33 escolas de educação infantil. $\bigcirc$ leitor pode indagar: isto é muito ou pouco? $\bigcirc$ documento também assinala que as creches comunitárias passaram a ser auxiliadas pelo poder público desde que em 1993, a Legião Brasileira de Assistência foi desativada.

Em 2001, em razão de praticamente inexistir creches comunitárias em condições de conveniamento, o poder público municipal iniciou um processo de discussão com a cidade, através do Orçamento Participativo, para construir novos espaços, entregando-os, em permissão de uso, para as associações de moradores administrá-las. Duas instituições de educação infantil já foram entregues [...] a construção de 28 instituições de educação infantil se encontra em estudos de viabilização de projetos ou em elaboração de projetos (PORTO ALEGRE, 2004b, p. 19).

Vinte e oito é ou não um número elevado? Importante assinalar que, seja qual for o histórico ou projeto em andamento, o executivo reconhece que " $a$ construção de novas instituições de educação infantil não atenderá às necessidades da cidade, pois, como no resto do país, em Porto Alegre é grande a demanda reprimida por educação infantil" (PORTO ALEGRE, 2004b, p. 19). O capítulo ainda analisa a questão da manutenção e desenvolvimento do ensino fundamental e médio. Aqui, o PME assinala que "está praticamente universalizado", ${ }^{21}$ mas aponta algumas carências causadas pelas migrações internas e reassentamentos. Destaca a criação da Educação de Jovens e Adultos EJA e do Movimento de Alfabetização (MOVA), respectivamente para a educação de jovens e adultos e para reduzir a população analfabeta da capital, assinalando que os mesmos se desenvolvem "mesmo sem financiamento específico."22 $\bigcirc$ Plano também refere que o governo mantém como política o atendimento de alunos com necessidades especiais, além de possuir contratos com instituições que prestam serviço especializado como equoterapia, natação especial e curso de libras. O ensino médio é garantido por duas escolas que o oferecem: a Escola Municipal de Educação Básica Dr. Liberato Salzano Vieira da Cunha e a Escola Municipal de Ensino Médio Emílio Meyer.

Portanto, o legalismo justifica a elaboração do PME, bem como o não investimento em ensino médio, o que é uma posição confortável, que retira do município a responsabilidade sobre o ensino médio. Lembremo-nos de que o legislador propôs sempre a atuação concorrente: as esferas são solidárias e agem conjuntamente nos três níveis. Se um determinado nível não oferece um serviço educacional, mesmo que não seja da sua competência, é obrigação do nível seguinte, se puder oferecê-la.

21 Porto Alegre, 2004b, p. 20.

22 lbid.

Ensaio: aval. pol. públ. Educ., Rio de Janeiro, v. 16, n. 61, p. 515-542, out./dez. 2008 
O que chama a atenção é que de certa forma, há uma preocupação em construir uma narrativa acrítica das políticas em andamento. As políticas do partido dos trabalhadores são apresentadas como fundadoras da ação educativa como se nunca antes do partido dos trabalhadores tivesse existido política educacional, pois os dados informados no PME retornam apenas até 1988. As políticas também são tomadas como o ponto de partida: elas são vistas como conquistas da categoria - e, de fato, em nível de salários e em diversas questões de ensino, houve um avanço notável - o problema é que tal discurso exclui o conflito que não deixa de se manifestar no plano real. Em reuniões do Fórum do PME, ou havia grupos de oposição, e aí, buscavam enfrentar e apresentar outras visões, ou havia o silêncio, que poderia significar duas coisas: ou a conformidade com o que estava sendo construído, ou a omissão da opinião simplesmente por sua inexistência.

Duas partes finalizam o capítulo. A primeira trata da garantia de direitos de que o governo e o PME se fazem aliados, referindo a necessidade de manter projetos e políticas que garantam a permanência do aluno na escola como oficinas, cultura, lazer e saúde. São apontados os gastos de vale transporte para que alunos participem de atividades culturais, além dos recursos aplicados em merenda escolar. A segunda parte merece atenção porque trata dos trabalhadores em educação. Diz, em sua introdução, que "os trabalhadores em educação convivem com baixos níveis salariais, precárias condições de trabaIho, múltiplas jornadas, provocando uma verdadeira crise de identidade" (PORTO ALEGRE, 2004b, p. 21). A partir daí, uma série de dispositivos legais é retomada para mostrar que é preciso investir no professor, tanto no nível salarial como na formação. A esse respeito, assinala o documento

na rede municipal de ensino de Porto Alegre, dois aspectos complementares se evidenciam como preocupações que foram delineando a política educacional: a ampliação dos espaços coletivos de formação na escola e a criação de novos instrumentos e estratégias de formação que potencializam a utilização desse espaço [...] a política de formação da rede municipal de ensino organiza-se a partir de assessoria direta às escolas, de seminários, fóruns, encontros regionais, cursos e conferências pedagógicas (PORTO ALEGRE, 2004b, p. 23).

É difícil avaliar o alcance real de tais iniciativas. Se por um lado, representaram a aproximação da rede de ensino daquilo que mais contemporâneo existe em termos pedagógicos e filosóficos identificamos, por outro, relatos da dificuldade que professores da rede de ensino sentem em transferir suas discussões para o espaço da sala de aula ou de que tais iniciativas e temas eram sempre "de cima para baixo". A pergunta é: ao defenderem tais práticas, como o ideal de trabalho, até que ponto ao longo do tempo em que foram praticadas efetivamente significaram um acréscimo qualitativo ao trabalho do professor? 


\section{Análise da "Educação básica como direito dos cidadãos e cidadãs"}

capítulo quatro, juntamente com o capítulo seguinte, constituem o centro do Plano. É o diagnóstico, seguido das metas e objetivos nível a nível, modalidade a modalidade de ensino. Nesta primeira parte temos um conjunto de definições: a educação se relaciona com a sociedade; a globalização produz desigualdades sociais; a democracia é um processo difícil devido à economia; o FMl impulsiona as reformas educacionais; os juros da dívida são superiores em gastos à educação e saúde; a LDBEN nasceu no contexto de estado mínimo; a escola brasileira nasceu para a elite; é função da escola colaborar para romper o ciclo da sociedade excludente e injusta. É uma escrita que revela, em parte, argumentos já consolidados no pensamento de esquerda.

Segue uma análise chamada "contexto municipal", onde é louvada a política do governo, que deu "maior organicidade às políticas educacionais e ao atendimento da educação" (PORTO ALEGRE, 2004b, p. 25). Aqui fica claro que, quem redigiu o texto base era da administração do governo "temos desenvolvido políticas de inclusão", diz o texto a certa altura. $\bigcirc$ problema é "temos", pois se o objetivo era formular um texto com origem na sociedade, "temos" aqui representa o Executivo, que num "ato falho" emerge do interior do texto que conduzia. Aqui não, assume que o discurso é do Executivo e não do Fórum. "A organização por Ciclos de Formação e as Totalidades do Conhecimento propõem um currículo transformador que permite a aprendizagem como processo contínuo de formação" (PORTO ALEGRE, 2004b, p. 25). Ora, somente um sujeito que participa da construção da proposta política e que teve acesso a construção deste documento pode considerar o sistema por ciclos perfeito. Novamente, é o modo como é construído o texto que apresenta problemas, pois idealiza aquilo que na realidade tem conflitos, impõe um discurso ideologicamente marcado, evitando, principalmente, que o texto possa revelar uma polifonia presente no processo, para além dos argumentos favoráveis e enobrecedores.

Se é verdade que "a qualidade e a quantidade de recursos físicos, materiais e humanos das escolas da rede têm um nível igualado apenas por poucas cidades no país", isso não significa que, na vida cotidiana, seus profissionais não enfrentem dificuldades de toda ordem, material, com o comportamento dos alunos e hostilidade de pais, pois é disso que se trata, de vincular a realidade a um pretenso discurso ideal que o PME contém e cuja origem está longe de ser esclarecida.

\section{Educação infantil}

O plano inicia com o diagnóstico da educação infantil. Aqui, o texto é importante porque faz uma recuperação da educação infantil na Prefeitura de Porto Alegre. Diz que a educação infantil era da ordem da Secretaria Municipal de Saúde e Serviço Social; que, na década de 40, jardins de infância eram localizados em praças públicas e que na década de 60 constituíram-se junto a escolas municipais e, muito mais tarde, nos anos 80, as creches municipais são criadas. Este registro evidencia o ritmo lento de atenção à população de zero a seis anos. É nos anos 90 que começam as novidades: 
Na década de 90 o poder público municipal conclui as obras das Casas da Criança e inova ao transferir as creches da Secretaria Municipal de Saúde e Serviço Social para a Secretaria Municipal da Educação, inaugurando assim o atendimento a esta faixa etária através de escolas de educação infantil" (PORTO ALEGRE, 2004b, p. 26).

O texto apresenta o dado de que o crescimento das matrículas na educação infantil cresceu cerca de 40\%, frisando que este aumento se deve à rede particular e comunitária. De fato, o que os dados revelam é a redução das matrículas (!), que passam de $5.852 \mathrm{em} 1997$ para $5.415 \mathrm{em} \mathrm{2003.} \mathrm{O} \mathrm{ponto} \mathrm{de} \mathrm{redução} \mathrm{teria} \mathrm{ocorrido}$ entre 1999 e 2000, quando turmas do Jardim B das escolas de ensino fundamental foram incorporadas ao primeiro ciclo do ensino fundamental. Segue um conjunto de tabelas e dados, demonstrando, por níveis e estabelecimentos, o número de matrículas na educação infantil.

\title{
Ensino Fundamental
}

O diagnóstico do ensino fundamental também inicia pela recuperação do histórico das relações deste nível. Destaca que entre 1949 e 1986, Porto Alegre manteve convênio com o Estado através do qual investia $20 \%$ dos valores de impostos na aquisição de imóveis e construção de prédios para as escolas estaduais, chegando a 230 escolas da Rede Estadual de Ensino. Entre 1986 e 2003, os estabelecimentos municipais de ensino fundamental em Porto Alegre, passaram de 41 para 47, e as respectivas matrículas saltaram de 31.832 para 50.701. Apesar de poucas escolas, as novas eram bem maiores que as já existentes na rede, dando início a um ciclo de educação de massa na Prefeitura de Porto Alegre. Diz o PME (PORTO ALEGRE, 2004b, p. 31):

\begin{abstract}
A rede municipal de ensino de Porto Alegre ampliou sua oferta em 18.869 matrículas, representando um crescimento de 59\%.Considerando o número de estabelecimentos de Ensino Fundamental pertencente á Rede Municipal, identifica-se um crescimento de aproximadamente 147\% no período de 1988 (19 escolas) a 2003 (47 escolas).
\end{abstract}

Um dado importante desta parte do trabalho é a defesa do processo de reestruturação curricular organizado desde 1994, "quando se desencadeia o Congresso Constituinte Escolar, cujas deliberações anunciam os Princípios da Escola Cidadã". Com a defesa da Educação Popular o sistema de ciclos é introduzido como a única forma de respeitar a especificidade da etapa de desenvolvimento de cada aluno. Para Azevedo (1999)

criou-se o laboratório de aprendizagem para os alunos com dificuldades, as turmas de progressão para os alunos com conhecimento defasado em relação à idade [...] redefiniram-se os tempos e e os espaços escolares [...] sintetizou-se uma nova consigna : Escola Cidadã.

Um dos estudiosos do tema em reprovação escolar Paro (2001) aborda as dificuldades da Educação por Ciclos, principalmente utilizando o argumento da necessidade do sistema, mas também de um esforço para evitar que o aluno, mesmo nos ciclos, chegue analfabeto. Para ele, a causa de seu fracasso está em não antecipar-se ao problema da reprovação no ciclo. É o mesmo que se 
observa naquilo que o PME aponta ao defender a adoção do FICAI - Ficha de Comunicação do Aluno Infreqüente -, pois muitos relatos de professores apontam para sua ineficácia como instrumento de garantia da permanência na escola "a gente faz a ficha, mas depois, o Conselho Tutelar não faz nada", argumenta um professor.

\section{Educação de Jovens e Adultos, Educação Especial e Ensino Médio}

Em nível de diagnóstico, o PME critica as iniciativas tradicionais dos anos 70 e 80. A educação de jovens e adultos era vista como instrumento de aumento de produtividade e não de cidadania. As iniciativas presentes da Prefeitura são o Serviço de Educação de Jovens e Adultos (SEJA), presente nas escolas municipais no turno da noite e que atende a população de trabalhadores com idade superior a 14 anos através de um currículo formal e o MOVA, Movimento de Alfabetização de Jovens e Adultos, realizado junto com entidades da sociedade civil que disponibilizam espaço físico e estabelecem convênios com o poder público municipal que arca com educadores populares. O MOVA iniciou com cerca de 2.340 alunos e hoje conta com cerca de 1750. Não há considerações interpretativas no texto acerca das razões desta redução.

A Educação Especial sozinha recebe mais atenção no plano que os programas do MOVA e SEJA. Em Porto Alegre, o documento estima que cerca de 194.500 pessoas apresentem deficiência. Uma interessante tabela apresenta dados do ano 2000 referindo o tipo de deficiência, especificando que a maior parte são deficientes visuais $(56,9 \%)$, seguindo-se cadeirantes $(36,2 \%)$, surdos $(25,6 \%)$, deficientes mentais (10,5\%). Paraplégicos ou a quem falta um membro varia de 3,4, a 1,4\%. Agora, os dados destacados são considerados falhos "por falta de indicadores, os dados apresentados não contemplam a demanda, uma vez que não existem programas para identificação, inclusive daqueles que não estão nas escolas" (PORTO ALEGRE, 2004b, p. 36).

O texto refere para além da insuficiência de informações que a política é ambígua. Por um lado, há na rede Escolas Municipais Especiais de Ensino Fundamental, que são atualmente 4; por outro, o atendimento de jovens com necessidades educacionais especiais ocorre junto com a restante clientela. As escolas especiais exclusivas possuem condições e projeto próprios. Por outro lado, temos relatos de dificuldades em escolas municipais freqüentadas por alunos com necessidades especiais. "Como fazer atendimentos sem preparo?" retrucou um professor; o trabalho de alguns professores é extremamente difícil em casos de autismo e psicose.

O texto do PME ao evidenciar tais ambigüidades indica que foi construído por pessoas que realmente estão em contado com os alunos portadores de necessidades educacionais especiais. Observa-se isso também pois o seu conteúdo não mantém um tom mais laudatório, ao contrário, reconhece a dificuldade de lidar com esta população e apresenta os problemas de identidade e cidadania que o tema coloca. Observemos esta passagem: 
Os indivíduos que apresentam deficiência mental, em sua maioria, acabam sendo representados por terceiros, enquanto demais pessoas com necessidades educacionais especiais organizam-se em associações e lutam, elas próprias, por seus direitos. O processo de inclusão nas escolas de ensino fundamental da rede regularé essencial e evidencia complexidade. È necessária uma infra-estrutura que extrapola a organização física dos espaços e diz respeito a uma rede de apoio e atendimento em que a escola seja também co-responsável por esse processo, mas não única. No tocante a escola, não só o professor deve estar comprometido e receberformação, mas todos os trabalhadores em educação" (PORTO ALEGRE, 2004b, p. 38).

Esta passagem é importante porque denuncia um conflito na elaboração do PME. Se em passagens anteriores, as escolas municipais eram as "mais bem estruturadas e mais bem aparelhadas", essa condição não se evidencia aqui. $\bigcirc$ que a passagem faz é denunciar a precariedade das condições da escola e de pessoal de apoio para o atendimento, a necessidade de formação e sobrecarga do professor em seu trabalho. $\bigcirc$ texto finaliza "por isso acreditamos e ratificamos a necessidade de investimento em educação especial desde a especialização de recursos humanos, bem como a ampliação da rede".

Finalmente, o nível do ensino médio é o único em que não houve avanço algum nos últimos anos. Isto não parece escandalizar os autores do PME. Os dados são prontamente apresentados. Enquanto que entre 1996 e 2002 a rede estadual passou de 50 escolas para 61, e a particular de 48 para 57, a rede municipal manteve-se com as mesmas duas escolas, sendo que uma delas atende também o ensino fundamental. Enquanto é estável o número de estabelecimentos, o número de alunos passa de 1.448 em 1996 para 1.652 em 2002, sugerindo oportunidades de superlotação dos estabelecimentos.

\section{Análise das "Diretrizes, objetivos e metas do Plano Municipal de Educação aprovadas no III Congresso Municipal de Educação"}

Esta é a parte mais problemática de todo o plano. A primeira característica é o esvaziamento da distinção entre diretrizes e metas. Diretrizes deveriam ser princípios, único local onde "teorizar" é admitido; metas deveriam apontar realizações concretas, indicar datas e apontar referências de base. Não é assim. No tema Gestão Democrática são apresentadas 86 diretrizes contra 36 metas; as diretrizes são quase o triplo das metas. Elas tratam de tudo: proteção integral, representação e participação, integração de ações públicas, realização de parcerias, discussões sobre acessibilidade; identificação de crianças com necessidades especiais, dentre outros tantos temas. Vejamos a primeira:

Promover, fortalecer, garantir e ampliar ações especificas, na perspectiva da proteção integral, articulando a sociedade civil, os segmentos da comunidade escolar, diversos órgãos públicos (da educação, saúde, assistência social, Conselhos Tutelares, Defensoria Pública, Ministério Público e Poder Judiciário) buscando acolhimento, a inclusão, a permanência e a aprendizagem dos(as) alunos(as) nas unidades de ensino deste serviço através dos diversos meios de comunicação (PORTO ALEGRE, 2004b, p. 42). 
Uma diretriz com esta amplidão fragiliza o PME. Nela tudo se inclui e por extensão, tudo pode ficar de fora. Como os órgãos públicos devem ser articulados; de que maneira participa a sociedade civil; como os meios de comunicação serão incorporados; afinal é para articular ou fortalecer, é para garantir ou ampliar? Se buscarmos o equivalente de metas, o que encontramos é: "A partir da vigência deste plano, promover periodicamente "campanhas" específicas para incidir na garantia da freqüência dos alunos, em parceria com os diversos órgãos públicos da educação, saúde, assistência social, Ministério Público e Conselhos Tutelares." (PORTO ALEGRE, 2004b, p 47). Nessa formulação, o que era para ser específico expressa-se sob o termo "campanhas", mas não especifica para que públicos, quantas por ano, se haveria temas especiais. Observe que de todos os conteúdos que eram buscados, "inclusão, permanência, aprendizagem", restou "freqüência" dos alunos.

A segunda característica é o esvaziamento da coerção. Qual é a capacidade real de pressão que possui um PME que é escrito nos termos de promover e fortalecer, aprofundar e viabilizar, aprimorar e articular? A formulação do PME não obriga ou exige nada. É quase como se os participantes do Fórum não tivessem legitimidade para exigir o que é denominado de direito à educação. É o que acontece com a ausência de indicações precisas do quanto, do que, do como as metas serão atingidas. Numa palavra, é a própria idéia de plano que é "desconstruída" no exato instante em que seu discurso é enunciado. Todo o texto de diretrizes e metas é substituído pelo conceito de "sugestão". Diretrizes trazem um significado de princípio, projeto ou conceito de base que não deve ser abandonado; já a sugestão faz parte do campo das opções, do que é facultado realizar. A distância que separa uma de outra está na relação que se estabelece entre os sujeitos.

Quem impõe diretrizes sabe que seu lugar da fala é superior. Ao contrário, sempre que "sugerimos" que algo seja desenvolvido, colocamo-nos na posição de uma fala inferior, não impositiva. O texto do PME ao sugerir medidas introjeta que cabe à SMED as verdadeiras decisões. È como se o Fórum desconhecesse que o processo, após legitimado pelo legislativo, torna-se obrigatório para o Executivo. Assim, algumas formulações do PME indicam que o que os participantes esperam é mais do mesmo, que entre assumir seu protagonismo e deixar à SMED a liberdade de fazer o que quiser como puder, preferem esta última.

A terceira característica é a diferença dos pesos entre diretrizes e metas. Partes menores receberam dezenas de diretrizes; partes importantes, poucas indicações. Vejamos as partes mais notáveis. Chama a atenção que sejam reduzidas as metas e diretrizes referentes ao Ensino Fundamental, que é reivindicado pelo PME como a principal área de atuação do município. Aqui temos 16 diretrizes para quatro (!) metas. Entre as diretrizes podem ser citadas: garantir o funcionamento do regimento escolar; garantir recursos financeiros e humanos que supram as necessidades pedagógicas; realizar conselhos avaliativos periódicos; universalizar o ensino fundamental; criar "volância" especializada nas turmas de alunos com necessidades especiais, dentre outros. As diretrizes põem em dúvida tudo o que foi dito nas páginas anteriores, pois funciona como um negativo do que ocorre na escola. Quer dizer, as diretrizes e metas correspondem também a uma falta. Nas escolas, em realidade, o regi- 
mento escolar é precário, os recursos financeiros e humanos colocados à disposição dos alunos são inferiores à suas necessidades, não há avaliações periódicas e nem sequer profissionais volantes, como propõe a Escola Ciclada. Poder-se-ia assim questionar: estaria mesmo universalizado o ensino fundamental em Porto Alegre?

E onde você observa concordância e conexão? Justamente na Educação Especial, que se fez representar tanto na parte de diagnóstico com ampla análise, como na parte de metas, superando níveis tradicionais de ensino. Para se ter uma idéia, só nesta parte são, aproximadamente, 46 diretrizes e 27 metas, total bem superior ao dedicado à Educação Fundamental, foco central da política municipal. É também de onde saem as metas mais precisas em termos de Plano Municipal de Educação, pois obriga o Executivo, "a partir da vigência" do plano, a iniciar medidas para melhoria dos espaços físicos, criar núcleos pedagógicos, enfim, tudo aquilo que é urgente para o atendimento dos portadores de necessidades especiais deve ser feito imediatamente. Outras metas, por outro lado, possuem prazos para seu cumprimento. É de dois anos o cumprimento da meta que obriga a garantir assessoria especializada em cada área de educação especial na escola, assim como é de dois anos o prazo para orientar a readequação dos projetos político-pedagógicos para os portadores de necessidades educativas especiais.

A terceira característica é que é um Plano para o público ver. Daí a preocupação com um item "Divulgação". Aqui, apropriar-se da mídia torna-se tão importante quanto o conteúdo. No item Inclusão/Divulgação (?) pode-se ler "Potencializar os mecanismos de ampla divulgação e esclarecimento do projeto educacional"; "divulgar as experiências das unidades de ensino, não somente os resultados, mas também a metodologia empreendida no projeto"; "promover e garantir canais de divulgação e efetiva publicação dos trabalhos e experiências"; "realizar pesquisas na comunidade escolar", "criar instrumentos que divulguem ao conjunto da sociedade as experiências em andamento". Nossa hipótese é que tal preocupação surge como reação à crítica à gestão da Escola Ciclada; trata-se de preocupações que, se legítimas, dizem mais respeito aos gestores da Secretaria Municipal de Educação do que ao quadro de professores.

Isto significa que a política educacional aspira a entrar na era do espetáculo. Esta é a estratégia encontrada pelos dirigentes da educação para fazer frente às críticas, que são publicas e feitas mediante a mídia, e que exigem uma resposta imediata pela mídia. Há nesta demanda também a idéia de que não são apenas os adversários do projeto político que devem ser enfrentados, mas a própria comunidade precisa ser seduzida novamente para o projeto.

A quarta característica é a fragilidade das políticas de financiamento defendidas frente às demandas apresentadas no PME. São ao todo 25 diretrizes e 9 metas, o que transforma o Plano num excelente plano de intenções com poucas condições de tornar-se real. As diretrizes tratam do acompanhamento da comunidade na aplicação dos recursos; da formação para essa fiscalização; da transparência dos recursos; da disseminação de informações sobre os recursos. Entretanto, apenas no sexto item surge a idéia de "comprometer a União, Estado e Município quanto ao financiamento da educação básica", além de "buscar aportes de outros recursos". Entretanto não fica claro o que é "comprometer"; seria ampliar recursos? 
Além das metas pouco ou quase nada objetivarem na ampliação dos recursos da esfera municipal, elas ainda tratam de legitimar as políticas em andamento, para "garantir a manutenção da vinculação constitucional de recursos", ou "garantir a autonomia da escola na gestão de recursos financeiros". Novamente, somente no item 13, retorna a questão central de "ampliar investimentos no fortalecimento e qualificação da educação". A meta 15, que trata de obrigar o estado a "garantir suporte financeiro para a concretização dos objetivos e metas deste Plano Municipal de Educação," termina por soar irreal, tal a distância de metas concretas.

As metas terminam por repetir a idéia de que transparência na gestão de recursos é suficiente para atender a educação. A primeira meta trata da publicação da aplicação das verbas; a segunda, trata de qualificar as formas de "socialização das informações"; a terceira, promover reuniões e seminários que supõe-se serem para fiscalizar ou divulgar recursos, já que não há informação sobre o seu fim; qualificar para melhor aplicar os recursos de que esse dispõe; garantir que a quota do salário educação seja administrada pela SMED; garantir que os recursos sejam repassados. Em nenhuma meta há exigência de aumento ou comprometimento de rendas ao menos municipais para a educação. Sem investir em metas para educação, em aumento de recursos, o Plano perde seu efeito prático.

\section{Conclusão}

A avaliação do PME é critica. Ele é um documento fundamental para o estabelecimento dos princípios de educação no município. Entretanto ele apresenta uma série de problemas de lógica de construção, paradigma discursivo, heterogeneidade entre metas e diretrizes, além de ocultar uma visão administrativa e ideológica das políticas em andamento.

Há uma ausência tanto no que se refere a tópicos do ensino fundamental, do financiamento da educação, sem falar da completa ausência da definição do legislativo como colaborador do sistema de ensino; ele só é visto como fiscalizador do plano, e instancia de legitimação.

Este estudo sugere três encaminhamentos. $\bigcirc$ primeiro é a revisão do texto base por uma comissão participante do Fórum, para retirar os aspectos ideologizantes ainda presentes no documento. Não se admite que um documento oficial, elaborado através de um sistema representativo de entidades, tenha como fio condutor a política do partido no poder. A análise de discurso crítico é também uma etapa necessária de sua elaboração.

O segundo é o reexame das metas pelo próprio Fórum, com o objetivo de especificar temas ainda não claramente delineados. A adoção de termos vagos e imprecisos, a ausência de metas quantificadas contribui para fragilizar o Plano Municipal de Educação. Por este motivo deve ser feito um esforço para resgatar a ausência de uma programação financeira e a repercussão das metas na ampliação de recursos municipais para a educação e na construção anual da Lei do Orçamento.

O terceiro é a indicação do parlamento como instituição suplementar ao sistema de ensino. Ela deve ser feita embasada em critérios que diferenciem sua participação, enquanto representante da sociedade em geral, da comunidade escolar que participou da elaboração do Plano Municipal. Deve-se, pois, tentar responder à pergunta: como mediar duas instâncias de representação entre si na avaliação da implantação do PME? 


\section{Referências}

AZEVEDO, J. C. A democratização da escola no contexto da democratização do Estado: a experiência de Porto Alegre. In: SILVA, L. H. Escola cidadã: teoria e prática. Petrópolis, RJ: Vozes, 1999.

BALL, S. J. Diretrizes políticas globais e relações políticas locais em educação. Currículo sem Fronteiras, [S.I.], v.1, n.2, p. 99-116, jul./dez. 2001.

BRASIL. Ministério da Educação, Cultura e Desportos. Plano Nacional de Educação (PNE). Apresentação de Vidal Didonet. Brasília, DF: Ed. Plano, 2000.

CORTESÃO, L.; MAGALHÃES, A.; STOER, S. Mapeando decisões no campo da educação no âmbito do processo da realização das políticas educativas.

Educação, Sociedade \& Culturas, Porto, PT, n.15, p. 45-58, 2001.

COSTA, B. M. Condições de vida em Porto Alegre: o que mostram os dados do censo demográfico 2000. In: PORTO ALEGRE (RS). Secretaria Municipal de Direitos Humanos e Segurança Urbana. Relatório de indicadores sociais de Porto Alegre 2002. Porto Alegre, 2003.

DELEUZE, G. Lógica de sentido. São Paulo: Perspectiva, 2002.

INEP. Mapa do analfabetismo no Brasil. Brasília, DF, 2003.

LOPES, A. C. Políticas curriculares: continuidade ou mudança de rumos?. Revista Brasileira de Educação, Campinas, SP, n. 26, p. 109-118, maio/ago. 2004.

MULLER, P.; SUREL, Y. A análise das políticas públicas. Tradução Agemir Bavaresco e Alceu R. Ferraro. Pelotas, RS: Educat, 2002.

PARO, V. Reprovação escolar. São Paulo: Xamã, 2002.

PÉCHEUX, M. Semântica do discurso: uma crítica a afirmação do óbvio.

Campinas, SP: Ed. da Unicamp, 1995.

PORTO ALEGRE (RS). Conselho Municipal de Educação. Parecer CME 008/2004. Manifesta-se favorável ao disposto no Plano Municipal de Educação de Porto Alegre. Pareceres. Porto Alegre, 2004a.

- Conselho Municipal de Educação. Plano Municipal de Educação de Porto Alegre. Porto Alegre, 2004b.

. Conselho Municipal de Educação. Regimento Interno do Fórum do Plano Municipal de Educação. Diário Oficial de Porto Alegre, Porto Alegre, p. 8-9, 4 jun. 2004c. Edição 2.296. 
PORTO ALEGRE (RS). Prefeitura Municipal. Lei Complementar n . 248, de 23 de janeiro de 1991. Cria o Conselho Municipal de Educação de Porto Alegre. Leis e Decretos, Porto Alegre, 1991. Disponível em: <http://lproweb.procempa.com.br/ pmpa/prefpoa/smed/usu_doc/leiCME.pdf>. Acesso em: 29 out. 2008.

. Prefeitura Municipal. Lei Municipal nº 8.198, de 18 de agosto de 1998. Cria o Sistema Municipal de Ensino de Porto Alegre. Legislação, Porto Alegre, 1998. Disponível em:

$<$ http://www.mp.rs.gov.br/infancia/legislacaoc/legislacaoc/id383.htm>. Acesso em: 27 ago. 2008.

. Prefeitura Municipal. Projeto de Lei do Executivo 62/2004. Institui o Plano Municipal de Educação e dá outras providências. Projeto de Lei, Porto Alegre, 2004d.

Recebido em: 02/07/2008

Aceito para publicação em: 15/10/2008 